\title{
Record
}

\section{Commander W. E. May, Royal Navy}

COMMANDER W. E. MAY, who died on 26 April I 989 , aged 89, enjoyed wide recognition for his writings on the early development of marine navigation and as a world authority on the history of compasses. He was also a specialist in what he himself described as 'the backwaters of Naval History'. Born at the turn of the nineteenth century and joining the Navy at the age of twelve, his long career fell into three distinct phases; in the Navy, with the Compass Department of the Admiralty and at the National Maritime Museum, Greenwich.

William Edward May was born on 10 November 1899, the son of Edmund May, solicitor, of Reading. He was educated at the Royal Naval Colleges at Osborne and Dartmouth, where he won the Naval History prize. His term was sent to sea in 1915 and he was appointed as Midshipman to HMS Téméraire - in which he was present at the Battle of Jutland - then as acting Sub-Lieutenant to the convoy sloop Lychnis, where he was mentioned in despatches for the sinking of $U$ 64. The end of hostilities saw the reintroduction of specialist courses, in all of which he obtained first class certificates.

After three years with the Hydrographic service in the survey ships Merlin and Flinders, May qualified in navigation in 1923 , subsequently serving in the battleship Valiant, the sloop Tring and the submarine depot ship, Adamant. In 1927 he transferred to the Emergency List at his own request and joined the firm of S. G. Brown as a gyro-compass inspector.

In 1929 May was offered a post at the Admiralty Compass Observatory (ACO), where he was to remain for the next 22 years, becoming a leading specialist and authority on gyro and magnetic compasses, both ancient and modern. At this time, the Director of the Compass Department had his own representatives (known as Superintendents of Gyro-compasses) in all H.M. Dockyards, providing a direct service to the Fleet, and May held the posts in Devonport (1933-6), Malta (1936-9) and Portsmouth (1939-42) where, to many a young Navigating Officer during the war, his name became almost synonymous with the $A C O$. Despite his rank and position, he was always prepared to 'take his coat off' and tackle a job himself if it would help to get a ship to sea more quickly. In $194^{2}$ he returned to headquarters and for the remainder of the war was responsible for organising gyro-compass installation and servicing throughout the country as well as for arranging the training and appointments of all compass swinging officers.

The many long train journeys necessitated by his duties in H.M. Ships around the country gave him ample time to begin his study of compass history and early in 1942 he began submitting articles to nautical and scientific journals - a practice he continued until well into his eighties. Whilst at first these dealt mainly with compass matters, on moving to the National Maritime Museum the scope of his writing widened to include many other aspects of naval history. More than I 50 articles appeared under his name, some of which were later included in other publications. In 1947 he took part in a BBC broadcast on the history of navigation, and in 1950 and 197 I he contributed the articles on the 'Compass' to the Encyclopaedia Britannica.

On joining the ACO in 1929 , May immediately took a close interest in its museum, 
a unique collection of magnetic compasses which was begun in 1837 for the benefit of the Admiralty committee which set up the Compass Department and had been added to over the years. Later, during the war, May took every opportunity to obtain examples of foreign compasses from our allies and, in due course, from German and Japanese sources. In 1969 he was concerned with the transfer of this unique collection to its present more logical home at the National Maritime Museum.

May himself left the ACO to become Deputy Director of the National Maritime Museum in 1951, a post for which his talents as a marine historian made him ideally suited and which he held until shortly before his sixty-ninth birthday. During this time he was responsible for the administration of the Museum and, curatorially, for the restoration of the Octagon Room and of Flamsteed House, the seventeenth-century Royal Observatory building which was opened by the Queen in 1960 .

In spite of his prodigious output of articles, there is still much of May's research material from the Public Record Office and historical libraries which, although never published, constitutes a valuable source of sifted data. It is now held by the National Maritime Museum. He was the author of three books on compass subjects as well as an authoritative History of Marine Navigation (1973) and the magnificently produced Swords for Sea Service (1970) - possibly the definitive treatise on the subject.

In 1947 May was one of the founder members of the Institute of Navigation and was elected into Fellowship two years later. He was also a very keen skier and continued his winter-sporting holidays until well into his seventies.

In 1924 he married Mary Elspeth Margaret James, who survives him.

A.E.F.

\section{Fourteenth annual meeting of the International Omega Association}

The International Omega Association will hold their 1989 annual meeting from 2-6 October at the Hotel Queen Mary, Long Beach, California, USA. The theme will be 'Omega : International and Economical'. The Technical Chairman is Ian Anderson, tel. 604-270-52 I 1 (ext. 45 II) and the Arrangements Chairman is Eric Swanson, tel. 619-553-3609. Further information from the International Omega Association, P.O. Box 2324 , Arlington, Virginia $22202-0324$, USA. 